\title{
ANTIOXIDANTS FROM MAIZE SEEDS AND ACCELERATED AGEING
}

\author{
Natalija Kravić ${ }^{1}$, Vesna Dragičević ${ }^{1}$, Marija Milivojevićn \\ Vojka Babić ${ }^{1}$, Slađana Žilić1
}

\begin{abstract}
Seed deterioration is expressed as the loss of viability, vigour and quality during ageing. The major causes of seed deterioration refer to free radical-mediated lipid peroxidation, enzyme inactivation or protein degradation, disruption of cellular membranes and damage to genetic integrity. Accelerated ageing (AA) is a simple method for studying the mechanisms of deterioration over short periods. In order to estimate the deterioration rate, seeds of four maize genotypes were exposed to accelerated ageing for different time points (three and six days of AA). In parallel, the same genotypes were evaluated regarding the content of total phenolics, phenolic acids, flavonoids and anthocyanins, as well as regarding total antioxidant capacity. Compared to non-stressed seeds, ageing was evidenced by decreased germination energy (48.9\%), a total number of seedlings (40.8\%) and seedlings growth (70.0\% for root length, $44.0 \%$ and $10.5 \%$ for root and shoot fresh weight, $5.0 \%$ for seed rest fresh weight, $12.0 \%$ and $11.5 \%$ for root and shoot dry weight, $15.3 \%$ for seed rest dry weight, respectively), as well as by an increased number of abnormal seedlings (22.0\%). Correlation analysis revealed that higher content of total phenolics, flavonoids and anthocyanins contributed to a higher radical scavenging activity, which was reflected through a lower level of deterioration rate, both regarding the energy of germination and overall seedling performance.
\end{abstract}

Key words: anthocyanins, flavonoids, germination energy, phenolic acids, total antioxidant capacity, vigour, Zea mays L.

\section{Introduction}

Seed ageing is a natural phenomenon that causes various physical, physiological and biochemical changes (Walters et al., 2010). These deteriorating events that occur within seed cells diminish the viability, vigour and quality of seeds, finally resulting in seed death (Lakshmi et al., 2021). Being programmed by genetic information specific to the species, seed ageing normally proceeds at a slower rate under the optimal conditions; however, under the stress imposed by adverse environment (i.e., sub-optimal conditions), it usually progresses at a faster rate (Groot et al., 2012). Relative humidity ( $\mathrm{RH})$ that controls seed moisture content and the temperature are the major factors that determine the seed deterioration rate. Although it should be mentioned that the process of artificial ageing might physiologically differ from the natural seed deterioration (Loycrajjou et al., 2008), accelerated ageing (AA) is a benchmark stress-test technique extensively employed in real-life seed processing to find the potential shelf-life of seed.

\footnotetext{
Original Scientific Paper (Originalni naučni rad)

${ }^{1}$ Kravić N, Dragičević V, Milivojević M, Babić V, Žilić S, Maize Research Institute Zemun Polje, S. Bajića 1, 11185 Belgrade, Serbia

*e-mail: nkravic@mrizp.rs
} 
Free radicals, i.e. reactive oxygen species (ROS), are unavoidable side-products of normal plant cell metabolism (Kurek et al., 2019). However, during natural or artificial ageing (i.e., accelerated ageing), the cellular homeostasis is disrupted, and the level of generated ROS is enhanced (Yu et al., 2021). Therefore, a proper balance between free radical production and scavenging is necessary for optimum physiological function. Antioxidants such as phenolic acids, flavonoids, and anthocyanins are potent free radical scavengers, thus contributing to the alleviation of ROS-induced oxidative damage (Deng et al., 2017).
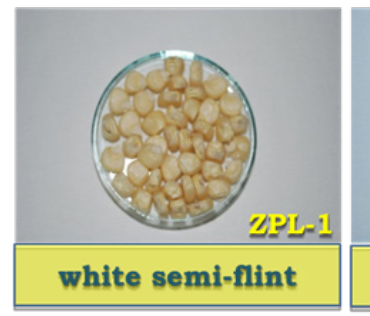

Accordingly, this study aimed to evaluate the possible protective role of different phenolic compounds from seeds by comparing the performance of maize seedlings obtained from non-stressed and accelerated aged seeds.

\section{Material and methods}

\section{Plant material}

Three inbred lines (of semi-flint and dent kernel type) and one local maize landrace (popcorn type) were used for this experiment. The genotypes were chosen on the basis of seed coat colour (Picture 1).

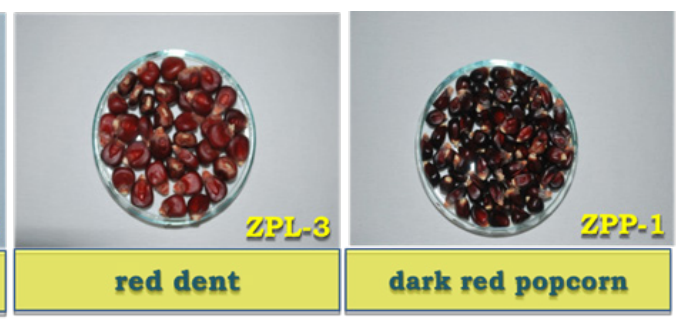

Picture 1. The evaluated maize genotypes Slika 1. Ispitivani genotipovi kukuruza

The inbred lines were selfed, while the landrace was multiplied via pair crossing by hand (i.e., full-sibling) in 2020 at Zemun Polje, Serbia $\left(44^{\circ} 52^{\prime} 00^{\prime \prime}\right.$ latitude $\mathrm{N}, 20^{\circ} 19^{\prime} 00^{\prime \prime}$ longitude E, $81 \mathrm{~m}$ altitude), in a two-replicate trial set up according to a randomized complete block design. Standard cropping practices were applied in the autumn and in the spring, before sowing. Also, weeds, pests and diseases were adequately controlled. After manual harvesting and drying to $14 \%$ water content, the genotypes were stored at medium-term conditions $\left(+4^{\circ} \mathrm{C}\right.$ and $\left.45 \% \mathrm{RH}\right)$ for five months until laboratory analyses. The list and the information on the evaluated maize genotypes are given in Table 1.

Table 1. Passport data and kernel type of examined maize genotypes Tabela 1. Pasoški podaci i tip zrna ispitivanih genotipova kukuruza

\begin{tabular}{lccc}
\hline Genotype (name) & Genotype type & Origin & Country of origin \\
\hline ZPL-1 & inbred line & CYMMIT (tropical) & Mexico \\
ZPL-2 & inbred line & $\begin{array}{c}\text { Iowa dent-local } \\
\text { population } \\
\text { Lancaster-sure crop } \\
\text { population }\end{array}$ & United States \\
ZPP-1 selfed & inbred line & United States & Serbia \\
\hline
\end{tabular}

CYMMIT - International Maize and Wheat Improvement Centre; MRI - Maize Research Institute 


\section{Laboratory analyses}

In Maize Research Institute (MRI) Seed Testing Laboratory, seeds were exposed to accelerated ageing at $42^{\circ} \mathrm{C}$ and $100 \% \mathrm{RH}$ for different time points (three and six days of accelerated ageing). Three biological replicates were performed for each treatment, as well as a germination assay with 50 seeds per replicate. Afterwards, the standard germination test, conducted according to the ISTA Rules (2018), was applied on both non-stressed (control seed) and accelerated aged seed. The between-paper method was used, at $20 / 30{ }^{\circ} \mathrm{C}$, with a photoperiod of $8 \mathrm{~h} / 16 \mathrm{~h}$ (light/dark). Evaluation of normal seedlings was done after four days (i.e., First count) and after seven days of germination (i.e., Standard germination).

Upon completion of the standard germination test, seedlings growth parameters were measured on ten seedlings per replicate, and obtained values were averaged. Seedlings length (L), as well as seedlings fresh weight (FW), were measured for shoot, root and seed rest separately. After oven-drying at $40{ }^{\circ} \mathrm{C}$ for $12 \mathrm{~h}$ until constant weight, seedlings dry weight (DW) was determined.

\section{Chemical analyses}

Chemical analysis regarding phenolic compounds content, conducted on non-stressed seeds only, was done in MRI Laboratory of Food Technology and Biochemistry. The idea was to evaluate to what extent the phenolic content per se (i.e., the content of antioxidants from non-stressed seeds) will contribute to a diminished deterioration rate imposed by accelerated ageing. For this purpose, maize seed samples of each genotype were milled into a fine powder (particle size $<500 \mu \mathrm{m}$, Perten 120, Sweeden).

Analysis of individual phenolic acids was done according to the method described by Žilić et al. (2012), with content expressed as $\mu \mathrm{g} \mathrm{g}{ }^{-1} \mathrm{DW}$. The total phenolics content was determined according to the Folin-Ciocalteau procedure (Hagerman et al., 2000) and expressed as $\mu \mathrm{g}$ of gallic acid equivalents (GAE) $\mathrm{g}^{-1} \mathrm{DW}$. The total flavonoids content was deter- mined according to Zhishen et al. (1999) and expressed as $\mu \mathrm{g}$ of catechin equivalents (CE) $\mathrm{g}^{-1} \mathrm{DW}$. Anthocyanins were extracted according to the slightly modified method described by Abdel-Aal and Hucl (2003), with content expressed as $\mu \mathrm{g}$ of cyaniding 3-glucoside equivalents (CGE) $\mathrm{g}^{-1} \mathrm{DW}$. The total antioxidant capacity, expressed as Trolox equivalent antioxidant capacity (TEAC) in $\mu \mathrm{mol}$ Trolox $\mathrm{g}^{-1} \mathrm{DW}$, was determined by the QUENCHER method (Serpen et al., 2008) using ABTS reagent and DPPH radical.

\section{Statistical analysis}

SPSS software for Windows, version 14.0 (SPSS Inc., Chicago, IL, USA), was used for the statistical analyses. Pearson's correlation coefficient is used to determine the relationship between the measured phenolic compounds content and the obtained seedlings performances.

\section{Results and discussion}

Seed ageing is a natural process and it is most frequently expressed as a reduction of germination, a process of which can be accelerated by unfavourable environmental conditions such as high humidity and temperatures (Machado Neto et al., 2001; Donohue et al., 2010). To achieve germination, the mature orthodox maize seed employs three main phases, starting with the imbibition (water uptake; phase I), which is followed by the germination sensu stricto (true germination process - lag phase; phase II), and ending with embryonic axis elongation and the radicle emergence (seedling growth; phase III) (Aragão et al., 2015). Both viable and non-viable seeds will exhibit phases I and II of water uptake, but only viable seeds are capable of entering phase III, which marks the completion of germination (Nonogaki et al., 2010). Compared to the nonstress seeds (i.e., control seeds), exposure to extreme humidity $(\sim 100 \%)$ during 3 -day AA treatment triggered the imbibition and resulted in an average increase of kernel fresh weight (KFW) for $28.3 \%$ in all genotypes evaluated. After 6-day AA treatment, a slightly more pronounced increase of KFW was observed, rang- 
ing from $31.1 \%$ to $32.3 \%$ to $36.3 \%$ for ZPL-1 (white inbred), ZPL-2 (yellow inbred) and ZPL-3 (red inbred), respectively. In dark red landrace, ZPP-1 was found the highest KFW increase of $43.3 \%$ (Figure 1).

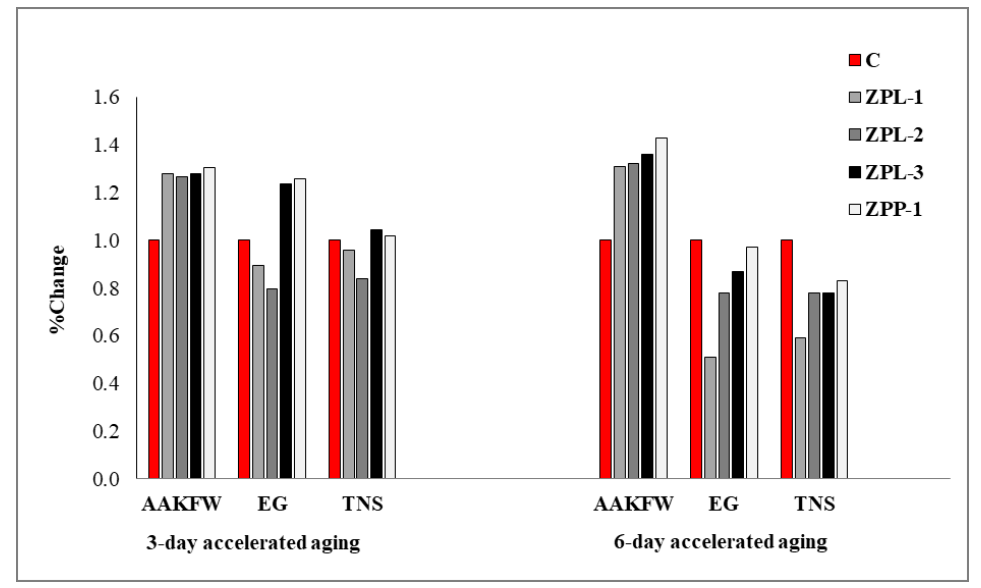

Figure 1. The effect of accelerated ageing on maize seedlings performance (the percentage of change for measured parameters; $C$ - values measured under optimal conditions given as $1(100 \%))$

Grafikon 1. Efekat ubrzanog starenja na performansu klijanaca kukuruza (procenat promene merenih parametara; C - vrednosti pri optimalnim uslovima date kao 1 (100\%))

It was reported that exposure to suboptimal conditions of accelerated ageing for $72 \mathrm{~h}$ (humidity of $\sim 100 \%$ and temperature of $44^{\circ} \mathrm{C}$ ), significantly decreases the germination rate and accelerates the deterioration of cellular components (Lakshmi et al., 2021). This is, to a higher extent, in line with our results. Namely, in comparison to the KFW, an opposite trend of change regarding the energy of germination (EG) was observed in response to AA treatments for the majority of evaluated genotypes (Figure 1). After 3-day AA treatment, the white ZPL-1 and yellow ZPL-2 inbreds exhibited decreased EG by $10.6 \%$ and $20.4 \%$, being the same genotypes that expressed the most pronounced EG decrease of $48.9 \%$ and $22.4 \%$ after 6 -day AA treatment, respectively. On the other hand, after 3-day AA, the red ZPL-3 inbred and dark red ZPP-1 landrace exhibited an EG increase of $23.7 \%$ and $25.7 \%$, respectively. Moreover, in study on maize hybrids that belong to the single cross varieties has not been found any significant change of germination rate during the first five to six days of accelerated ageing compared to control seed (Simić et al., 2004).
In response to decreased germination rate and accelerated deterioration of cellular components, the increased requirement for repair leads to a delay to radicle emergence and reduced germination performance, ultimately failing to germinate and loss of seed viability (Rajjou et al., 2012). In our study, as with the $\mathrm{EG}$, the same trend of change in response to AA treatments was observed for a total number of seedlings (TNS). After 3-day AA, the red ZPL-3 inbred and dark red ZPP-1 landrace exhibited a slight TNS increase of $4.3 \%$ and $2.1 \%$, respectively. After 3-day AA, the white ZPL-1 and yellow ZPL-2 inbreds exhibited decreased TNS by $4.1 \%$ and $16.0 \%$, being the same genotypes that expressed the most pronounced TNS decrease of $40.8 \%$ and $22.0 \%$ after 6 -day AA, respectively (Figure 1).

In addition, seed ageing not only delays radicle emergence but, in many species leads to abnormal or weak seedlings (Powell and Matthews, 2012). Compared to the non-stressed (i.e., control) seeds, the effect of AA treatments resulted in a highly significant increase of the number of abnormal seedlings (NAbS), ob- 
served in white ZPL-1 (thirteen-fold at 3-day AA and fifteen-fold at 6-day AA) and ZPL-2 inbreds (two-fold increase at 3-day AA and eleven-fold at 6-day AA), respectively. In comparison to control seeds, red ZPL-3 inbred expressed the absence of abnormal seedlings under 3-day AA; however, 6-day AA resulted in a seven-fold NAbS increase. The best performing genotype in terms of the appearance of abnormal seedlings was the dark red popcorn ZPP-1 landrace (75.0\% NAbS decrease at 3-day AA and the same level of NAbS as nonstressed seeds at 6-day AA) (Figure 2).

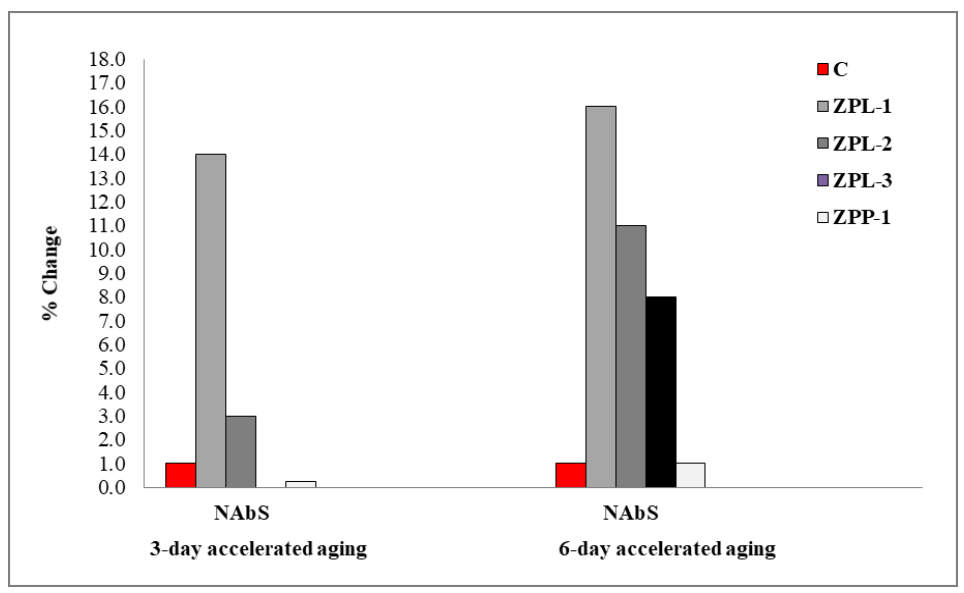

Figure 2. The effect of accelerated ageing on the number of abnormal maize seedlings (the percentage of change for measured parameter; $C$ - values measured under optimal conditions given as $1(100 \%)$ )

Grafikon 2. Efekat ubrzanog starenja na broj nenormalnih klijanaca kukuruza (procenat promene merenog parametra; C - vrednosti pri optimalnim uslovima date kao 1 (100\%))

The study on a variety of plant species reports that seedlings root and shoot length are significantly decreased after each period of accelerated ageing but the rate of reduction was not varying significantly within the same plant species (Govindaraj et al., 2017). In our study, it was not the case for 3-day AA treatment, since the majority of evaluated maize genotypes exhibited increased seedlings root length (RL) by 6.7\% (ZPL-1), 13.8\% (ZPL-2) and 5.8\% (ZPP-1), respectively, while ZPL-3 was the only inbred that showed $5.0 \%$ of RL decline. However, in response to 6-day AA, seedlings RL decreased by $69.0 \%, 40.0 \%, 29.4 \%$ and $16.7 \%$ in ZPL-1, ZPL2, ZPL-3 and ZPP-1, respectively (Figure 3).

As with the seedlings RL, the same trend of change in response to accelerated ageing was found for seedlings shoot length (SL). Under the 3-day AA treatment, SL increase ranged from $18.9 \%$ in ZPL-1 to $48.0 \%$ in ZPP-1, being slightly pronounced under 6-day AA treatment (from $5.5 \%$ in ZPL-1 to $74.9 \%$ in ZPP-1 increase, respectively) (Figure 3 ). The same trend in seedlings growth parameter expression, i.e. increased SL, could be explained by the fact that the seedling growth is a morphogenetic expression of genetic programming. This morphogenetic expression leads to elongation of radicle and plumule at a more or less defined rate under a particular environmental condition. Under the similar environmental condition, which is in our case 3-day or 6-day AA treatment, the growth of the seedlings takes on a defined temporal pattern, which is the manifestation of the sum, total of activities increasing cell number, cell expansion, fresh and dry weight. Alterations of the environmental condition can modify the seedling growth in different ways affecting various growth parameters (Kapoor et al., 2010). 


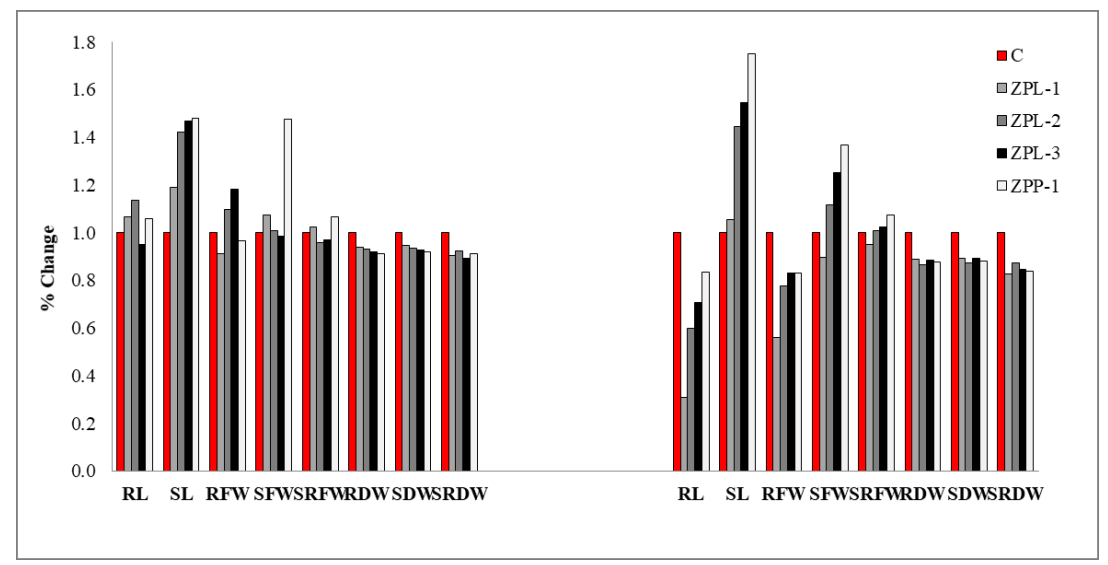

Figure 3. The effect of accelerated ageing on maize seedlings growth parameters (the percentage of change for measured parameters; $C$ - values measured under optimal conditions given as $1(100 \%)$ )

Grafikon 3. Efekat ubrzanog starenja na parametre rasta klijanaca kukuruza (procenat promene merenih parametara; C - vrednosti pri optimalnim uslovima date kao 1 (100\%))

Concerning the changes in seedlings root fresh weight (RFW) and shoot fresh weight (SFW), as well as the seed rest fresh weight (SRFW), the evaluated genotypes exhibited quite opposite trends in response to AA treatments (Figure 3 ). The majority of the genotypes showed a decline in RFW (from 3.5\% to 9.0\% decline under 3-day AA treatment), being more pronounced under 6-day AA treatment (from $17.1 \%$ to $44.0 \%$ decrease under 6-day AA treatment). In opposite to RFW, the majority of the genotypes showed an increase in SFW (from $0.8 \%$ to $47.7 \%$ increase under 3-day AA treatment), being also more pronounced under 6-day AA treatment (from $11.7 \%$ to 36.9 $\%$ decrease under 6-day AA treatment). The exceptions were the red ZPL-3 (1.4\% SFW decline at 3-day AA) and the white ZPL-1 (10.5\% SFW decline at 6-day AA) inbreds. As with the SFW, the same trend of change in response to AA treatments was observed for SRFW. The average increase in SRFW was $4.5 \%$, being quite the same for both 3-day AA and 6-day AA treatments. Moreover, the same genotypes that exhibited a decrease in SFW also exhibited a decrease in SRFW (i.e., 3.0\% decline at 3-day AA for ZPL-3 and 5.0\% decline at 6-day AA for ZPL-1, respectively).
In response to accelerated ageing, the same trend in change was observed for root dry weight (RDW), shoot dry weight (SDW) and seed rest dry weight (SRDW). At 3-day AA, average RDW, SDW and SRDW reduction was $7.5 \%, 6.8 \%$ and $9.2 \%$, respectively. At 6-day AA, slightly pronounced reductions were observed (i.e., an average decrease of $12.0 \%, 11.5 \%$ and $15.3 \%$ for RDW, SDW and SRDW, respectively) (Figure 3). Our results are in line with the reported decreased cotton seedlings dry and fresh weights, and seedlings length upon accelerated ageing (Basra et al., 2003). The observed seedlings DW decrease, associated with a reduction in various growth parameters (EG in particular) of artificially aged maize seedlings, can be considered as a reflection of biochemical and hormonal imbalance. The possible reason for this reduction might be the lowering of biochemical activities in seeds enzymes that are necessary to convert reserves within the embryo to a usable form and ultimately production of normal seedlings (Kapoor et al., 2010).

Reactive oxygen species (ROS) produced during imbibition are an important causative factor of seed ageing, although significantly ROS also play critical roles as signalling fac- 
tors that promote germination (Kranner et al., 2010). To minimize damage to cellular structures and biological molecules from exceeded seed imbibition that occurs during accelerated ageing, orthodox seeds have evolved powerful protection and repair systems, such as increased synthesis of phenolic compounds (Powell and Matthews, 2012). Phenolics (phenolic acids, simple and complex flavonoids and coloured anthocyanins) are an important and the most pronounced group of secondary metabolites found in plants, with a variety of physiological roles including ROS scavenging, enzyme activation, photoprotection, and signal regulation (Babbar et al., 2014).

The increase in studies on understanding of vigour has stimulated the investigation of biochemical components and their function in the physiological quality of seeds since these compounds can be used as biomarkers through the manipulation and enrichment of the tissue's composition (Yan et al., 2014). To determine the influence of the phenolic compounds content per se (i.e., in non-stressed seeds) on seedlings performances upon accelerated ageing, maize genotypes of different seed coat colours were chosen.

It has been reported that the genotypes with more pigmented seed coats are more resistant to imbibitional damage (conditions of deteriorated-humidity induced by AA treatments) than are pale varieties, and with higher germination rates (Gomes and Garcia 2013). In the present study, in comparison to control seeds performance, the dark red seeds of ZPP-1 and the red seeds of ZPL-3 showed high germination rate $(97.1 \%$ and $86.8 \%$, respectively); whereas the yellow seeds of ZPL-2 and the white seeds of ZPL-1 exhibited $78.6 \%$ and $41.1 \%$, respectively. The colour formation at seed coat is mainly attributed to the presence of phenolic compounds such as flavonoids and anthocyanins. According to biochemical analyses, the yellow ZPL-2 inbred expressed the highest total flavonoid content $(281.20 \mu \mathrm{g} \mathrm{CE}$ $\left.\mathrm{g}^{-1} \mathrm{DW}\right)$, followed by red ZPL-3 inbred, dark red ZPP-1 landrace and white ZPL-1 maize inbred (i.e., 267.58, 270.54 and 248.64 $\mu \mathrm{g} \mathrm{CE} \mathrm{g}^{-1}$ DW, respectively).
The availability of phenolics as natural antioxidants was reported to be one of the seed quality parameters (Dona et al., 2013). The seed antioxidants reduce lipid oxidation, protect the genetic material and essential biomolecules and delay the ageing in seed tissues (Kumar et al., 2015). The highest total phenolics content $\left(6044.5\right.$ and $6114.7 \mu \mathrm{g} \mathrm{GAE} \mathrm{g}^{-1}$ DW) was achieved by anthocyanin-rich ZPL-3 and ZPP-1 genotypes (with 15.43 and 696.07 $\mu \mathrm{g}$ CGE $\mathrm{g}^{-1} \mathrm{DW}$ of anthocyanin, respectively), followed by a lower total phenolic content (5227.1 and 5392.2 $\mu \mathrm{g} \mathrm{GAE} \mathrm{g}^{-1} \mathrm{DW}$ ) achieved by the anthocyanin-free ZPL-1 and ZPL- 2 inbreds. Chemical analysis revealed the presence of phenolic acids as antioxidants with potent free radicals quenching ability important for maintaining the homeostasis of ROS (Ma et al., 2016), and the most abundant individual phenolic acid was ferulic acid, with an average value of $2796.48 \mu \mathrm{g} \mathrm{g}^{-1} \mathrm{DW}$, followed by $p$-Coumaric (320.53 $\left.\mathrm{gg} \mathrm{g}^{-1} \mathrm{DW}\right)$, and $o$-Coumaric acid $\left(15.55 \mu \mathrm{g} \mathrm{g}^{-1} \mathrm{DW}\right)$.

Increased generation of ROS during the germination process could be neutralized by phenolic compounds, due to their antioxidant capacity (Tiwari et al., 2018). In the present study, the antioxidant capacity of seeds (TEAC) has been determined as the free radical scavenging ability using ABTS (2,2-azino bis/3-ethyl-benothiazoline-6-sulfonic acid) reagent, as well as a stable DPPH (2,2-duphenyl-1-picrylhydrazyl) radical. Seeds of evaluated maize genotypes exhibited different antioxidant capacity using ABTS reagent: the dark red (ZPP-1) and red (ZPL-1) genotypes achieved the highest TEAC (i.e., 28.3 and $26.7 \mu \mathrm{mol}$ Trolox $\mathrm{g}^{-1} \mathrm{DW}$ ), followed by yellow ZPL-2 $\left(19.8 \mu \mathrm{mol}\right.$ Trolox $\mathrm{g}^{-1}$ DW) and white ZPL-1 inbreds (15.9 $\mu \mathrm{mol}$ Trolox $\left.\mathrm{g}^{-1} \mathrm{DW}\right)$, respectively. The same trend in TEAC, although slightly lower, was obtained by DPPH radical (i.e., 29.2, 26.1, 16.0 and 13.7 $\mu \mathrm{mol}$ Trolox $\mathrm{g}^{-1} \mathrm{DW}$, respectively). A strong positive correlation between the phenolic compounds content and the antioxidant capacity has been observed (Pang et al., 2018), which is highly in line with our results ( $r=0.991$ and $r=0.994, p \leq 0.001$ between total phenolics content and TEAC (ABTS) and TEAC (DPPH)). 
The speed of cellular repair activities (such as the synthesis of phenolic compounds) that facilitate recovery from exceeded seed imbibition during accelerated ageing, and the antioxidant capacity for this repair, are closely linked to germination performance and the successful establishment of the young seedling (Powell and Matthews, 2012), which is fully in line with the results obtained in this study (Table 2). Beside significant positive correlations with total phenolics, flavonoids and anthocyanins, the highest significant positive correlations were observed between TEAC (ABTS) and germination performance (i.e., EG: $r=0.947$; TNS: $r=0.853$ and NAbS: $r=-0.856, p \leq 0.001$, respectively), i.e. successful establishment of the young seedling (RL: $r=0.949$; SL: $r=0.934$; RFW: $r=0.881$; SFW: $r=0.974$ and SRFW: $\mathrm{r}=0.925, p \leq 0.001$, respectively).

Table 2. Correlations between \% change of maize seedlings growth parameters in response to accelerated ageing and antioxidants content in seed

Tabela 2. Korelacije izmedu \% promene parametara rasta klijanaca kukuruza izazvane ubrzanim starenjem $i$ sadržaja antioksidanasa u zrnu

\begin{tabular}{|c|c|c|c|c|c|c|c|c|}
\hline \multirow{2}{*}{$\begin{array}{l}\text { Seedlings } \\
\text { growth } \\
\text { parameters } \\
\text { (\% change) }\end{array}$} & \multirow[t]{2}{*}{$\begin{array}{c}\text { Total } \\
\text { phenolics }\end{array}$} & \multirow[t]{2}{*}{ FA } & \multirow[t]{2}{*}{$p$-CoumA } & \multirow[t]{2}{*}{$o$-Coum A } & \multicolumn{2}{|c|}{ TEAC } & \multirow[t]{2}{*}{$\begin{array}{c}\text { Total } \\
\text { flavon }\end{array}$} & \multirow[t]{2}{*}{ Total anth } \\
\hline & & & & & ABTS & DPPH & & \\
\hline KFW & $0.883^{\star * *}$ & 0.109 & -0.524 & $-0.832^{* * *}$ & $0.892^{* * *}$ & $0.928^{* * *}$ & 0.280 & $0.925^{\star * *}$ \\
\hline EG & $0.894^{\star * *}$ & 0.123 & -0.028 & $-0.650^{*}$ & $0.947^{\star * *}$ & $0.895^{\star * *}$ & $0.698^{\star}$ & $0.652^{\star}$ \\
\hline TNS & $0.775^{\star *}$ & 0.256 & 0.190 & $-0.614^{\star}$ & $0.853^{* * *}$ & $0.771^{\star *}$ & $0.843^{\star * *}$ & 0.551 \\
\hline NAbS & $-0.782^{\star *}$ & -0.198 & -0.215 & 0.555 & $-0.856^{* * *}$ & $-0.770^{\star *}$ & $-0.844^{\star * *}$ & -0.497 \\
\hline RL & $0.898^{\star * *}$ & 0.127 & -0.050 & $-0.665^{\star}$ & $0.949^{\star * *}$ & $0.902^{\star * *}$ & $0.685^{\star}$ & $0.671^{\star}$ \\
\hline SL & $0.877^{\star \star \star}$ & 0.186 & -0.045 & $-0.705^{\star}$ & $0.934^{* * *}$ & $0.886^{\star * *}$ & $0.699^{*}$ & $0.698^{*}$ \\
\hline RFW & $0.818^{\star *}$ & 0.065 & 0.199 & -0.460 & $0.881^{* * *}$ & $0.795^{\star *}$ & $0.803^{\star *}$ & 0.431 \\
\hline SFW & $0.934^{\star * *}$ & 0.065 & -0.144 & $-0.668^{*}$ & $0.974^{\star * *}$ & $0.940^{* * *}$ & $0.610^{*}$ & $0.702^{*}$ \\
\hline SRFW & $0.871^{\star * *}$ & 0.234 & -0.129 & $-0.780^{\star *}$ & $0.925^{\star * *}$ & $0.893^{* * *}$ & $0.645^{\star}$ & $0.780^{\star *}$ \\
\hline RDW & 0.082 & $-0.771^{\star *}$ & $-0.780^{\star *}$ & 0.345 & -0.053 & 0.077 & $-0.897^{\star * *}$ & -0.066 \\
\hline SDW & 0.137 & $-0.930^{* * *}$ & $-0.593^{\star}$ & 0.536 & 0.005 & 0.099 & $-0.770^{\star *}$ & -0.260 \\
\hline SRDW & -0.119 & 0.432 & $0.951^{* * *}$ & 0.057 & -0.004 & -0.161 & $0.867^{\star * *}$ & -0.307 \\
\hline
\end{tabular}

KFW - kernel fresh weight; EG - energy of germination; TNS - total number of seedlings; NAbS - number of abnormal seedlings; RL - seedlings root length; SL - seedlings shoot length; RFW - seedlings root fresh weight; SFW - seedlings shoot fresh weight; SRFW - seed rest fresh weight; RDW - seedlings root dry weight; SDW - seedlings shoot dry weight; SRDW - seed rest dry weight; FA - ferulic acid; $p$-CoumA $p$-Coumaric acid; $o$-CoumA - o-Coumaric acid; TEAC - total antioxidant capacity ${ }^{*}, * * * * *$ significant at $p \leq 0.05 ; 0.01$ and 0.001 probability level, respectively

Accordingly, evidences on the correlation of phenolic compounds, antioxidant capacity and seed quality parameters substantiate that the phenolics coupled with antioxidant capacity could enhance the quality seed parameters by protecting from mechanical and chemical damage in maize (Kumar et al., 2020).

\section{Conclusion}

The study prompted us to conclude that biochemical analysis regarding phenolics content is a powerful tool for screening the physiological quality of maize seeds and to predict the seed vigour of the samples, thus providing a basis for the genetic improvement of maize cultivars that 
aim at higher physiological seed quality. It has been shown that genotypes with higher antioxidants content per se exhibited less pronounced changes in seedlings growth parameters during stress induced by accelerated ageing, and in such a way evidencing the positive relation of these bioactive compounds with the improved vigour of the seeds. High-vigour seeds, being with pigmented seed coat, have shown to be more tolerant to stress and this higher tolerance is associated with higher total phenolics, flavonoids and anthocyanins content, as well as with higher total antioxidant capacity.

\section{Acknowledgements}

This research was supported by the Ministry of Education, Science and Technological Development, Republic of Serbia, under Grant no. 451-03-68/2020-14/200040.

\section{References}

Abdel-Aal ESM, Hucl P (2003): Composition and stability of anthocyanins in bluegrained wheat. J. Agric. Food Chem., 51: 2174-2180.

Aragão VPM, Navarro BV, Passamani LZ, Macedo AF, Floh EIS, Silveira V, Santa-Catarina $C$ (2015): Free amino acids, polyamines, soluble sugars and proteins during seed germination and early seedling growth of Cedrela fissilis Vellozo (Meliaceae), an endangered hardwood species from the Atlantic Forest in Brazil. Theor. Exp. Plant. Physiol., 27: 157-169.

Babbar N, Oberoi HS, Sandhu SK, Bhargav VK (2014): Influence of different solvents in extraction of phenolic compounds from vegetable residues and their evaluation as natural sources of antioxidants. J. Food Sci. Technol., 51: 2568-2575.

Basra SMA, Ahmad N, Khan MM, Iqbal N, Cheema MA (2003): Assessment of cotton seed deterioration during accelerated ageing. Seed Sci. Technol., 31: 531-540.

Deng B, Yang K, Zhang Y, Li Z (2017): Can antioxidant's reactive oxygen species (ROS) scavenging capacity contribute to aged seed recovery? Contrasting effect of melatonin, ascorbate and glutathione on germination abil- ity of aged maize seeds. Free Radic. Res., 51, 765-771.

Dona M, Balestrazzi A, Mondoni A, Rossi G, Ventura L, Buttafava A, Macovei A, Sabatini ME, Valassi A, Carbonera D (2013): DNA profiling, telomere analysis and antioxidant properties as tools for monitoring ex situ seed longevity. Ann. Bot., 111: 987-998.

Donohue K, Casas RR, Burghardt L, Kovach K, Willis CG (2010): Germination, postgermination, adaptation, and species ecological ranges. Annu. Rev. Ecol. Evol. Syst., 41: 293-319.

Gomes MP and Garcia QS (2013): Reactive oxygen species and seed germination. Biologia, 68: 351-357.

Govindaraj M, Masilamani P, Selvaraju P, V. Alex Albert V (2017): Effect of accelerated ageing on germination and seedling vigour of manually and mechanically harvested and threshed rice seeds. Int. J. Agric. Sci. Res., 7: 39-48.

Groot SPC, Surki AA, de Vos RCH, Kodde J (2012): Seed storage at elevated partial pressure of oxygen, a fast method for analyzing seed ageing under dry conditions. Ann. Bot., 110: 1149-1159.

Hagerman AE, Harvey-Mueller I, Makker HPS (2000): Quantification of tannins in the foliage-a. In Laboratory Manual; FAO/IAEA: Vienna, 2000.

ISTA Rules (2018): International Rules for Seed testing. Published by The International Seed Testing Association (ISTA), Bassersdorf, Switzerland. Available at https://doi. org/10.15258/istarules.2018.F

Kapoor N, Arya A, Siddiqui MA, Amir A, Kumar H (2010): Seed Deterioration in Chickpea (Cicer arietinum L.) under Accelerated Ageing. Asian J. Plant Sci., 9: 158-162.

Kranner I, Minibayeva FV, Beckett RP, Seal CE (2010): What is stress? Concepts, definitions and applications in seed science. New Phytol., 188, 655-673.

Kumar SP, Rajendra Prasad S, Banerjee R, Thammineni C (2015): Seed birth to death: dual functions of reactive oxygen species in seed physiology. Ann. Bot., 116: 663-668.

Kumar SPJ, Kumar A, Ramesh KV, Singh C, Agarwal DK, Pal G, Kuchlan MK, Singh R 
(2020): Wall bound phenolics and total antioxidants in stored seeds of soybean (Glycine max) genotypes. Indian J. Agric. Sci., 90: 118-122.

Kurek K, Plitta-Michalak B, Ratajczak E (2019): Reactive oxygen species as potential drivers of the seed aging process. Plants, 8: 174.

Lakshmi CJ, Jijeesh CM, Seethalakshmi KK (2021): Impact of accelerated aging process on seed quality and biochemical changes of Dendrocalamus sikkimensis Gamble. Acta Physiol. Plant., 43: 34.

Loycrajjou LY., Steven PC, Groot BM, Job C, Job D (2008): Proteome wide characterization of seed aging in Arabidopsis. A comparison between artificial and natural aging. Prot. Plant Physiol., 148: 620-641.

Ma D, Li Y, Zhang J, Wang C, Qin H, Ding H, Xie Y, Guo T (2016): Accumulation of phenolic compounds and expression profiles of phenolic acid biosynthesis-related genes in developing grains of white, purple, and red wheat. Front. Plant Sci., 7: 528.

Machado Neto NB, Custodio CC, Takaki M (2001): Evaluation of naturally and artificially aged seeds of Phaseolus vulgaris L. Seed Sci. Technol., 29: 137-149.

Nonogaki H, Bassel GW, Bewley JD (2010): Germination-still a mystery. Plant Sci., 179: 574-578.

Pang Y, Ahmed S, Xu Y, Beta T, Zhu Z, Shao Y, Bao J (2018): Bound phenolic compounds and antioxidant properties of whole grain and bran of white, red and black rice. Food Chem., 240: 212-221.

Powell AA and Matthews S (2012): Seed aging/repair hypothesis leads to new testing methods. Seed Technol., 34: 15-25.

Rajjou L, Duval M, Gallardo K, Catusse J, Bally J, Job C, Job D (2012): Seed germination and vigor. Annu. Rev. Plant Biol., 63: 507-533.

Serpen A, Gökmen V, Pellegrini N, Fogliano V (2008): Direct measurement of the total antioxidant capacity of cereal products. J. Cereal Sci., 48: 816-820.

Simić A, Sredojević S, Todorović M, Đukanović L, Radenović C (2004): Studies on the relationship between the content of total phenolics in exudates and germination ability of maize seed during accelerated aging. Seed Sci. Technol., 32: 213-218.

Tiwari TN, Kumar SPJ, Tiwari AK, Agarwal DK (2018): Seed coating in relation to minimizing the effects of seed ageing in rice (Oryza sativa L.). J. Rice Res., 10: 27-32.

Walters C, Ballesteros D, Vertucci VA (2010): Structural mechanics of seed deterioration: Standing the test of time. Plant Sci., 179: 565-573.

Yan D, Duermeyer L, Leoveanu C, Nambara $E$ (2014): The functions of the endosperm during seed germination. Plant Cell Physiol., 55:1521-1533.

Yu S, Zhu X, Yang H, Yu L, Zhang Y (2021): A simple new method for aged seed utilization based on melatonin-mediated germination and antioxidant nutrient production. Sci. Rep., 11, 5937.

Zhishen J, Mengcheng T, Jianming W (1999): The determination of flavanoid contents in mulberry and their scavenging effects on superoxid radicals. Food Chem., 64: 555-559.

Žilić S, Serpen A, Akıllığlu G, Gökmen V, Vančetović J (2012): Phenolic compounds, carotenoids, anthocyanins and antioxidant capacity of colored maize (Zea mays L.) kernels. J. Agric. Food Chem., 60: 122412-122431. 


\title{
ANTIOKSIDANTI IZ SEMENA KUKURUZA I UBRZANO STARENJE
}

\author{
Natalija Kravić, Vesna Dragičević, Marija Milivojević, Vojka Babić, Slađana Žilić
}

\begin{abstract}
Sažetak
Propadanje semena se ogleda u gubitku životne sposobnosti, energije i kvaliteta. Dejstvo slobodnih radikala dovodi do peroksidacije lipida, inaktivacije enzima, degradacije proteina, razaranja ćelijskih membrana i oštećenja genetičkog materijala, i smatra se glavnim uzrokom propadanja semena. Ubrzano starenje, kao metod, omogućava proučavanje mehanizama propadanja semena u kratkom vremenskom periodu. Za procenu stepena propadanja, seme četiri genotipa kukuruza je izloženo tretmanu ubrzanog starenja u trajanju od tri i šest dana. Uporedo sa ovim, kod istih genotipova je ispitivan sadržaj ukupnih fenola, fenolnih kiselina, flavonoida i antocijana, kao i ukupni antioksidativni kapacitet. Poređenjem sa nestresiranim semenom (kontrola), starenje je rezultiralo padom energije klijavosti (48,9\%), smanjenjem ukupnog broja klijanaca (40,8\%), smanjenjem rasta klijanaca (70,0\% za dužinu korena, 44,0\% i 10,5\% za svežu masu korena i izdanka, 5,0\% za svežu masu semenog ostatka, 12.0\% i 11.5\% za suvu masu korena i izdanka, $15.3 \%$ za suvu masu semenog ostatka, respektivno), kao i povećanjem broja nenormalnih klijanaca (22,0\%). Korelacionom analizom je utvrđeno da je povećani sadržaj ukupnih fenola, flavonoida i antocijana doprineo većoj sposobnosti gušenja slobodnih radikala, reflektujući se kroz smanjen stepen propadanja semena, kako u pogledu energije klijavosti, tako i u pogledu ukupne performanse klijanca.

Ključne reči: antocijani, flavonoidi, energija klijavosti, fenolne kiseline, ukupni antioksidativni kapacitet, vigor, Zea mays L.
\end{abstract}

Primljen: 29.11.2021.

Prihvaćen: 14.12.2021. 